\title{
Policing political protest in Lithuania
}

\author{
Arunas Juska and Charles Woolfson
}

\section{Linköping University Post Print}

N.B.: When citing this work, cite the original article.

The original publication is available at www.springerlink.com:

Arunas Juska and Charles Woolfson, Policing political protest in Lithuania, 2012, Crime, law and social change, (57), 4, 403-424.

http://dx.doi.org/10.1007/s10611-012-9363-4

Copyright: Springer Verlag (Germany)

http://www.springerlink.com/?MUD=MP

Postprint available at: Linköping University Electronic Press

http://urn.kb.se/resolve?urn=urn:nbn:se:liu:diva-77459 


\title{
Policing political protest in Lithuania
}

\begin{abstract}
This article analyzes policing political protest in post-independent Lithuania. It argues that since the early 2000s, policing of political protest as an issue has increased in importance as Lithuania has experienced political mobilization and radicalization among groups disadvantaged by postcommunist reforms. It is suggested that police responses reveal precursor tendencies towards growing authoritarianism which has become more visible in the most recent period. In 2008, the onset of deep economic crisis across the region has generated rising social unrest (including outbreaks of street riot) as a result of government adoption of severe austerity measures. The article examines the growing centralization and militarization of policing and the increasing criminalization of public protest, as well as the restriction and litigation of organized dissent by authorities. At the same time, it also points to the internal contradictions of austerity programs which lack popular legitimacy both at the level of the state and society, including more vocal and militant labor unions; increasing challenges to the drift towards a new authoritarianism by the courts; and, paradoxically, the emergence of growing labor unrest within police force itself, with the potential to undermine authoritarian tendencies in policing 'from within.' The wider implications of (re)turn to post-communist authoritarianism in public order policing are discussed.
\end{abstract}




\section{Introduction}

As European governments impose austerity measures in the aftermath of the global economic and financial crisis, the public order policing of growing social unrest has become an issue of policy concern both for both national governments and supranational actors such as the World Bank and the European Union (EU) [1],[2]. In terms of the role of policing in democratic society, the global crisis has produced challenges to the strategies and tactics of policing mass protests. While not new in themselves, such challenges interrogate the boundaries of legitimate public protest in the new 'age of austerity.' Attention hitherto has mainly focused on public disorders accompanying mass demonstrations on the streets of major European cities such as London, Barcelona, Lisbon and Athens. Less noticed have been episodes of social unrest in the new democracies of Eastern Europe [3],[4]. Some of the newer EU member states have however experienced protracted economic downturn on a severe scale during the global economic and financial crisis, most notably, the Baltic states of Estonia, Lithuania and Latvia and in the latter two in particular, there have been episodes of violent austerity-driven social unrest [5],[6].

Ironically, having been previously extolled for their success in creating 'tiger economies' with the highest rates of growth in the EU, a number of commentators have begun to point to the Baltic states as providing exemplary models of successful austerity management. When in the second quarter of 2010 Lithuanian economy grew by $1.1 \%$ for the first time since contracting by $14 \%$ in 2008-09, a number of commentators began to assert the success of 'internal devaluation' policies in stabilizing financial systems in the region [7], [8], [9]. The Baltics were lauded as an example to be followed by the other countries, first of all to deeply indebted P.I.I.G.S (Portugal, Italy, Ireland, Greece and Spain). There were claims of the supposed 'maturity' of the electorate in the region and celebration of 'vibrant' democracies that took in stride hardships of the 
recession and endured them in order to implement the necessary market 'corrections' [10]. Most importantly, it was claimed that the prescription of harsh cuts in social spending and wages has been administered by Baltic governments without unwelcome side-effects in the form of social unrest. Thus, interviewed in mid-2010 during the very depth of the crisis by Steve Forbes, the eponymous editor-in-chief of Forbes magazine, the Lithuanian prime minister Andrius Kubilius reflected on the 'success' of his government's raft of austerity measures. These policies amounting to a so-called 'internal devaluation', had taken the form of cuts in wages, pensions and reductions in mass living standards in order to secure both fiscal stability and future membership of the single European currency (the euro). Baltic Lithuania was duly praised by Steve Forbes as one of 'Europe's unsung heroes'. "Not every recession-hit country in Europe is like wayward Greece, Portugal and Spain” Forbes enthused, adding for good measure, “amazingly Lithuanian unions went along with the government's policies. There were no street riots à la Greece” [11].

In contesting this selective version of contemporary Lithuanian history, the emergence of significant social unrest (including 'street riot') in response to government austerity measures is detailed. Moreover the trade unions at least initially, far from going along with government policies played a pivotal role in mobilizing these protest demonstrations. A more comprehensive reading of contemporary events is offered by Hudson and Sommers who critique financial commentators (notably in the Wall Street Journal and The Economist) keen to promote the adoption of 'the Baltic austerity model' to Greece, Ireland and Spain [7,12,13]. Hudson and Sommers suggest that the Baltic states can hardly be regarded as exemplars of the supposed 'maturity' of the electorate in accepting the need for sacrifices (the Latvians having just reelected a pro-austerity government in 2010) [14]. Instead they ascribe purported popular 
passivity to government austerity programs producing a deleterious mix of pauperization of the most vulnerable sections of society, spiraling levels of unemployment, mass emigration and, in the case of Baltic Latvia, the deployment of anti-Russian ethnic rhetoric in order to retain a politically divided and compliant electorate [15],[16]. Here, as in neighboring Lithuania, the absence of a strong labor movement capable of sustained opposition is identified as impeding more organized and vigorous popular protest movements from emerging. While a more insightful analysis of 'Baltic quiescence', one crucial explanatory variable is neglected, the role of state power through the agency of policing and administrative proscription in suppressing popular discontent following its initial eruption. In contrast to both of the above interpretations therefore, the focus in this article is primarily on the (re)turn towards authoritarian practices of policing and secondarily on the bureaucratic manipulations of the local state in containing popular protest.

The rise of authoritarian tendencies in policing in Central and Eastern Europe has been noted by a number of authors characterizing it as a drift towards 'illiberal democracy' [17] or a trajectory of 'out of and into authoritarian law' [18]. Expressions of authoritarianism, in turn, can be analytically differentiated into two closely related but distinct realms: everyday policing and policing of political protest. The rise of authoritarianism in everyday policing is usually associated with significant increase in and pervasiveness of fear of crime across post-communist countries. Thus, according to Maria Loss, rapid social changes in the region following collapse of Communism had led to growing perceptions of general social disorder, insecurity and powerlessness of the state. As a result, 'fear of the state' was replaced by 'fear of crime'[19],[20]. A pervasive fear of crime and victimization, in turn, led to a number of responses from proliferation of private security arrangements[21] to demands by the public for a 
strengthening of 'the law and order' and 'getting tough on crime', often resulting in the singling out of disadvantaged and minority groups within the population [22, p. 86-90].

If crime and its policing are mostly related to threats from opportunistic individuals and groups of individuals (organized crime) and tend to be localized in particular areas and among particular social groups, policing political protests by contrast at its extreme can represent a task of upholding public order against large groups of people provoked and mobilized by social, economic and political grievances (i.e., unpopular decisions by authorities). In other words, fear of political protests tends to be associated with perceptions of threats of large scale disorder and anarchy. ${ }^{1}$ Furthermore, unlike police engagement with criminals, provision of security during demonstrations usually involves coordination and negotiation with protest organizers and local authorities on the course of public actions and safety measures. Where such strategies of cooperative engagement are deemed insufficient, policing responses can include military style deployment of large police and army formations, numerous detentions and arrests as well as use of water cannons, mounted police and dogs, tear gas, and rubber bullets. Therefore, even when ethos of "law and order" prevails in everyday policing and influences strategies and tactics of policing political protest, the influence is not direct, but is usually mediated by a number of factors that can facilitate or, on the contrary, constrain authoritarian tendencies in both, political and policing realms [23], [24], [25]. Among these the most important are the character of protest cultures that have legitimized and prescribed preferred repertoires of collective action, especially in restrictions on or propensity towards legal civil disobedience, or, on the contrary, illegal and violent actions [26], [27]; the role of changing political opportunity structures in the country, the impact of mass media, as well as the specifics of strategic interactions leading to escalation or 
de-escalation, such as action-reaction dynamics among those that are engaged in participating in as well as the policing of political protests [28], [29].

King and his co-authors were probably the first scholars to identify and analyze growing authoritarianism in policing in Lithuania[24]. In their study they pointed out that the trend towards de-militarization of Lithuanian police which was initiated with reforms of the early 1990s was reversed and replaced by its para-militarization. By 2007 Public Security Service (PSS) was established under the purview of the Ministry of Interior subsuming the two former Ministry of Interior troops. The PSS is a paramilitary unit of 1,000 officers trained and equipped to suppress and riots and mass unrest. Their study also pointed out a 'law and order mentality' "becoming fairly entrenched <in public order policing> whereby the police unreflectingly follow the 'letter of the law' rather than exercising discretion and engaging in flexible negotiation" [ 24 , p. 432; 436]. If the first development-paramilitarization--referred to structural change within the force, the second development--strengthening of 'law enforcement' mentality--was indicative of increasing militarization of policing in general, i.e., de-emphasizing the role of officers as providers of service to citizens and communities and instead treating them as surrogate soldiers following the orders from superiors.

In this paper we rely on and extend further King et al's study by pointing out that concerns over a drift towards authoritarianism in policing in general, and policing of political protest, in particular, were particularly heightened by an increase in political and social unrest across the region associated with the onset of deep economic crisis in 2008. Economic recession hit less developed countries on the periphery of Eastern and Southern Europe disproportionally hard and generated the largest wave of anti-government protests since collapse of Communism in 1991. Characteristic in this respect was the situation in Baltic Lithuania which in early 2009 
was to be shaken by a particularly violent mass protest demonstration provoked by unpopular government austerity policies.

Increasing social tension and social unrest began to change policing priorities, as securing public order became one of the foremost preoccupations for the authorities, often leading to growing restrictions on freedom of gathering and expression. In Lithuania this trend was dubbed as a drift towards 'Belarussification' of policing suggesting an increasing use by authorities of repressive strategies and tactics similar to the ones employed by authoritarian leader Lukashenko in the neighboring Belarus [30],[31]. These practices include increasing militarization of policing, the introduction of new administrative and legal controls over public protests (denial of permits for protests and demonstrations; restricting the size of protest actions; limiting protest venues to locales in remote suburbs, etc.); and increasing surveillance by the state of those who are deemed to be its potential 'enemies' as well as their intimidation via threats of and the actual use of various legal and administrative measures, including those of detention and prosecution.

In this paper we argue that militarization became the prevailing approach to policing protest in Lithuania in the current austerity era, and it is derived from and resembles war-fighting tactics, with military style intelligence, equipment provision and training geared to achieving battlefield success. This militarization was also expressed in the strengthening of what was, in essence, the military ethos of police officers, especially in their interaction with citizens, publically manifested in military-style deployments, strict subordination and obedience to superiors, with the goal to attack and destroy 'the enemy.' Virtually absent from both the discourse and practice of austerity public order policing, has been the core democratic acknowledgement that protesters were not 'the enemies' and that demonstrations and rallies were not 'enemy operations' to be either disrupted or prevented altogether, far less that these 
demonstrators are also citizens exercising their constitutional rights in which the role of policing is to enable to them to do so in safety and security.

Similarly, there has been a clearly pronounced trend, towards an increasing number of arbitrary administrative prohibitions and restrictions on political protest that in some cases has resembled a virtual bureaucratic sabotage of rights to free speech and public assembly. As a result, in the last two to three years litigation and resort to court action became almost a routine way for civic groups and political parties to obtain permits for public rallies in the face of municipal authorities which now routinely delayed, dragged out, restricted, and prohibited demonstrations.

At the same time, we point to internal contradictions in the pursuit of authoritarian enforcement as a strategy for dealing with political protest in the era of austerity, including first, rising organized opposition (more vocal and militant labor unions) and second, a countervailing and increasing contestation by the courts challenging the drift towards a new administrative authoritarianism; third, and paradoxically, we note the emergence of growing labor unrest within police force itself, with the potential to undermine authoritarian enforcement 'from within.' While these emergent contradictions speak to the democratic advances of two decades of postcommunist transformation, nevertheless such gains now hang in the balance. Policing 'dissent' has become the 'acid test' of democratic renewal. The protracted global and economic crisis, therefore offers insight into the precise limits of democratic policing in societies with 'thin' as well as 'thick' democracies [32].

In this paper a number of data sources were used. We used secondary analysis of Lithuanian statistics, police and court reports, and examination of relevant public opinion surveys. We also relied on media surveys including Lietuvos Rytas, (leading Lithuanian daily 
newspaper), Delfi.lt (leading portal of daily news in the country), and other national and international news media coverage of austerity politics, political protest and its policing in Lithuania and neighboring Baltic countries. We also used our own data collected in the last decade while studying policing, grass roots organizing and labor movements in the Baltics which includes extensive interviews and discussion with police officers and officials, academics, community and labor organizers and others (see also [33]).

We begin our analysis with an overview of policing political protest in Lithuania since the late 1980s until the early 2000s with an especial emphasis on precursor authoritarian strategies inherited from the Soviet period. Then we outline the scale of the recent economic crisis and consequential social unrest, together with the dynamics of the state's response to organized opposition in terms of its public order policing strategies. Finally, we explore the contradictions and possible limits of a (re)turn to post-communist authoritarianism.

\section{Policing Protest in post-Soviet Lithuania}

The predecessor of the Lithuanian police, the Soviet militia was a tool of totalitarian and authoritarian control of society by the Communist party and all forms of public demonstration were treated as illegal provocations against the regime. In order to effectively survey and suppress any political dissent, the police force was highly centralized and militarized. A peculiar characteristic of the militia in Soviet Lithuania was its ethnic stratification: while the top leadership of the Lithuanian militia consisted mostly of ethnic Russians, many middle rank and rank-and-file officers were ethnic Lithuanians. Because of its ethnic composition, Moscow distrusted the militia in Lithuania fearing that Lithuanian officers might engage in acts of insubordination against the regime and even fraternize with political protesters. Thus, in the only 
significant mass protest against the Soviet power in Lithuania prior to perestroika in 1972 in Kaunas, in the second city of Lithuania and its nationalist heartland, Moscow sidelined local militia and relied mostly on KGB and internal troops to surround and disperse an anti-Soviet demonstration of about 3,000 people and arrest 402 participants [34]:252-253].

Moscow's apprehension about the questionable loyalty of the militia in Lithuania was confirmed when perestroika ushered an era of anti-Soviet mass rallies and demonstrations. By the late 1990s the Lithuanian militia began to disintegrate along ethnic lines, with the overwhelming majority of ethnic Lithuanian officers taking an oath of allegiance to the separatist government. Being unable to rely on the militia, Moscow deployed a detachment of the notorious OMON troops from Russia (Special Purpose Police Unit of the Soviet Interior Ministry used for a combination of commando and riot suppression tasks) in attempt to intimidate and suppress the separatist movement. The OMON left a gruesome and bloody trail in Lithuania, including the killing of 14 unarmed civilians and injuring close to 700 others when in January 1991 its paratroopers attempted to storm and seize the TV tower in Vilnius.

In the immediate post-independence era, the rump wing of what was the former Soviet militia was renamed and reassigned into Lithuanian national police force. Ethnic Russians who previously served in the force, especially in the top positions, left Lithuania and returned to Russia. The police force was no longer used for political surveillance and persecution. However, in all other respects, especially in its structure and functions, there was little difference between the Soviet militia and the newly constituted Lithuanian police. Furthermore, the militarization and centralization of the force only increased. In part, this was because up until August 1993, a contingent of more than 20,000 Russian troops remained stationed in the country. As negotiations with the Yeltsin government over their withdrawal continued, the Lithuanian police 
force was tasked to serve in the role of a surrogate military force protecting the government and its institutions against the continuing threat posed by the presence a foreign army.

Even when Russian troops had left the country, the militarization of the police remained pervasive because of exponentially rising rates of crime, and especially of organized crime. In chaotic immediate post-independence conditions, violence, insecurity and fear of crime became omnipresent and the police responded with at times violent clampdowns on organized crime. Laws on organized crime were changed to facilitate such police actions; the para-military commando style detachment Aras was established to carry out surveillance, control and apprehend the Lithuanian mafiosi [35]. It was only by 1997, when the most prominent organized crime syndicates in Lithuania had been dismantled that the first attempts to restructure, decentralized and de-militarize the force were initiated [36].

In the meantime, political protests following the re-establishment of Lithuanian independence declined dramatically as all countries across the region experienced political demobilization. In conditions of deep economic recession in the early post-Soviet years day-to-day survival became the most urgent preoccupation of the population. However, views about the role of police in society inherited from the Soviet era remained deeply entrenched. The police were thought by the public to be primarily a crime-fighting institution. There was little awareness or appreciation of the notion that policing also represented a service to citizens and communities. Therefore most efforts in reforming the police in the late 1990s early 2000s were directed at increasing its effectiveness in fighting crime, combating corruption within the force, and in implementing more effective ways to address complaints over mistreatment by citizens [37], [38]. 
This situation began to change in the early 2000s, mostly under the impact of a radicalization of Lithuanian politics and the widening scope of political protests associated both with farmers' blockades in the face of agricultural restructuring and with the deep political crisis produced by President Paksas' impeachment and removal from office. In response to growing threats to public safety and security, the police reforms that had begun in 1997 stalled and were gradually reversed in a pronounced drift towards authoritarianism in policing political protest. This was expressed in growing para-militarization of the police, culminating in the establishment in 2007 of the Public Security Service (PSS). The PSS was a paramilitary unit of about one thousand officers trained to suppress riots and mass unrest. The newly created municipal police departments with supposed local accountability vis-à-vis their regional and national counterparts experienced an erosion of their autonomy. Finally, there was a strengthening of the 'law and order' mentality in policing as plans for remaking the police as a public service institution were mostly abandoned. This meant diminishing the role of discretion and flexibility in the exercise of authority by rank-and-file officers and a diminution of their public accountability. Instead police officers were seen mostly serving as surrogate soldiers carrying out the orders of superiors and following the letter of the law [24].

By the early 2000s the increasing scale of political protests became indicative of growing class tensions and conflicts in the country which pitted 'the winners' against 'the losers' in Lithuania's post-communist transformation [39]: 247-249. Thus, on one side of this conflict were increasingly affluent urban middle classes who successfully adapted to the new service and knowledge-based economy and whose lifestyles and consumption patterns closely resembled those of the middle classes in Western Europe. On the opposite side were 'the losers', mostly large segments of less educated Soviet-era industrial and agricultural workers who had lost their 
jobs and savings in the processes of privatization, monetary reforms, and de-industrialization and restructuring and who could not adjust to the new post-communist realities.

In March of 2000 Lithuanian sugar beet growers driven to the brink of bankruptcy by deep and protracted crisis in post-communist agriculture, organized a series of protests and marches that culminated in a blockade of Lithuania's major highways. Blockades were repeated in Fall of 2000 and in Spring of 2001. In this latest instance, the conflict that emerged on the 'via-Baltica' highway near the Polish-Lithuanian border was ultimately resolved by force. As negotiations between farmers and police at the border broke down, police officers moved in to clear the roads and forest tracks. The culmination was confrontation and sustained violent clashes relayed on Lithuanian television, with shocking scenes of police truncheon blows being delivered upon the heads of protesters. A reflective article on these events noted that, "we are step by step approaching social unrest ... although the conflict soon died down, there was a smell of gunpowder in the air" [40]:13].

Political mobilization and radicalization of those disadvantaged by post-communist reforms became especially prominent during the investigation, impeachment trial, and subsequent removal from presidential office of Rolandas Paksas (from February 2003 through to April 2004) [41]. Paksas had won presidential elections on the basis of populist appeals to the 'other Lithuania,' supposedly forgotten and abused by 'the new elites.' He had campaigned mostly in smaller economically depressed towns and villages and was able effectively to tap into widespread disillusionment over the post-communist reforms and to portray himself as a populist strongman promising to fight widespread corruption and re-establish 'justice and order' in the country. 
However, very early in his presidency Paksas was implicated in relationships with shady figures from the Russian criminal underworld [42]. As 'Paksgate' erupted, followed by demands for impeachment and removal from office, his followers mobilized and rallied in support of the besieged president, arguing that by staging a trial 'the ruling elites' were attempting via unconstitutional means to unmake the results of the presidential election and were intent on sabotaging the 'corruption cleanup and restoration of justice' program.

During a tumultuous year of large scale pro- and anti-Paksas rallies and demonstrations apprehension grew over the possibility of rapidly escalating political conflict turning into street violence and riots. Of especial concern was the increase in public profile and presence at the proPaksas rallies of small neo-Nazi fringe groups. 'Troopers' of the so-called 'Lithuanian Patriotic Union' dressed in black Nazi style uniforms took upon themselves to protect and provide safety to the besieged president, mainly by threatening to beat up and engaging in scuffles with antiPaksas demonstrators.

One of the police responses to growing importance of issues of crowd control was an increasing centralization and para-militarization of the force [24]. However, the continuing underlying drift towards authoritarian policing during the early 2000s occurred not only because of growing threats to public order as various segments of the population became increasingly politically radicalized. It was also significantly shaped by the ambivalent responses to political protest shaped by the legacy of the Soviet era. As tensions and discontent in society increased, so too did the authoritarian reflexes of authorities, especially in regard to public protests. These were duly treated not as a welcome and overdue expression of a long-lamented absence of civic engagement of various groups in society, or as constructive dialog with authorities, and the exercise of constitutional and human rights to free expression and freedom of assembly. Instead, 
the authorities from prime minister and the speaker of the Seimas to local municipalities tended to regard these localized protest actions as disturbances, annoyances, as superfluous 'noise', or something negative which should be pushed out of sight to remote suburbs. There was also a tendency to demonize protesters as 'an enemy' which by a very fact of staging a public gathering had declared 'a war' on the authorities. At its rhetorical extreme participation in actions expressing a democracit right to dissent were delegitimized as gatherings of boorish, uncultured and easily manipulated simpletons [43]. As we will see, faced with a new wave of social unrest and political protests accompanying the beginning of recession in 2008, authoritarianism in policing, already present since the early 2000s, was to become particularly problematic.. In order to situate these events, we next examine the scale of the economic downturn which engulfed the Baltic states in the late 2000s and subsequent popular reaction to austerity in Lithuania.

\section{'Hard Landing' and Social Unrest in Lithuania}

Following the collapse of the Soviet Union at the beginning of the nineteen nineties, all three Baltic states had adopted of neo-liberal 'open market' policies of economic and social reconstruction designed to promote foreign direct investment [44], [45]. By the middle of the present decade, the Baltic states collectively dubbed 'tiger economies', had received a special accolade for their efforts in introducing free market reforms from the World Bank [46]. The successful economic transition was marked by steadily high growth levels of GDP from the beginning of 2000 onwards, and particularly since joining the EU in 2004 until 2008. The unwelcome corollary of higher GDP growth rates, was that it was largely based on the development of unsustainable economic activity such as speculative property development and credit-based personal consumption, financed by external liquidity. 
When the economic downturn finally arrived in the latter part of 2008 , the relative sharpness of the economic decline occasioned by the crisis was significantly greater than the average for the EU. By the 4th quarter of 2009 compared to the previous year, GDP in Lithuania had decreased by $13.2 \%$, while unemployment skyrocketed from 4 to $14 \%$ and became one of the highest in the EU [47],[48].

The 'hard landing' in the Baltics became all the harder as lending in Lithuania by foreign investors had been mostly denominated in Euros (up to 90\% of the total) [49]. Since currency devaluation as one potential response option of the Baltic governments, posed a threat not just to lenders and foreign investors but to domestic borrowers and investors as well, it was ruled out by the government. Instead a 'fiscal route' out of the crisis was chosen to be achieved by 'internal devaluation', in other words a radical reductions in wages, especially in the public sector and a massive retrenchment of public expenditure.This harsh economic medicine was accompanied by revisions to the labour code which made it easier for employers to dismiss workers without incurring huge costs.

These anti-crisis austerity measures of the new Lithuanian government were hastily devised and rushed into law in day and night sessions during December of 2008 in order to be in place before the start of the new taxation year. The three trade union confederations, precieving a direct attach on their members' living standards and job security, called for a united protest demonstration in the form of a warning strike in late January 2009.

The largest demonstration was to be held in Vilnius on 16 January 2009. It took place one week after a similar demonstration in Riga capital city of Latvia. This had ended in civil disorder - the first such occurrence of significant social unrest in a new EU member states since the onset of the crisis. In Vilnius the demonstration comprised some seven thousand persons both young 
and old, gathered in freezing temperatures and heavy snowfall in one of the largest popular gatherings since independence. Coordinated trade union-led protests also took place in at least half a dozen smaller towns and cities that had rarely seen trade union demonstrations before. In the capital, the mass assembly outside the Seimas began in an orderly fashion with the leaders of the various trade union confederations addressing their supporters.

However, after the trade unions and their supporters had departed, a sizeable crowd of 300 to 400 people remained. There were repeated calls for government ministers to speak with the demonstrators. A recurrent theme of the demonstration was the perception that the livelihood of people had now been 'stolen' by the elites. Demonstrators began pelting the parliament windows with eggs and stones. Finally, there was a surge forward as protesters attempted to enter the parliament building which police officers guarding the doors found increasingly difficult to contain.

Within moments, formations of riot police, members of the Public Security Service, took up position. According to police records, there were 511 police personnel near the Seimas: 361 regular officers and 150 riot police. The latter were dressed in full body armor, wearing black balaclavas and tear-gas masks, armed with truncheons, shields and carrying rifles which could discharge rubber bullets and, not least, accompanied by dogs. Some personnel were wearing khaki battle fatigues. Someone in the crowd threw a smoke flare, and the phase of civil unrest began [50].

For the several hours, as pavements were torn up to provide missiles, riot police and protesters hurled tear-gas canisters at each other in running battles. Thick clouds of tear gas drifted across Independence Square adjacent to the parliament. By the end of the day fifteen people were hospitalized with various types of wounds, one of them in was reported to be in a 
critical condition with a bullet wound in head; 151 individuals were detained by the police, 49 were later charged for actions during the disturbances; damage to buildings and other property was estimated to be close to 2 million Litas $(\$ 800,000)$ [51].

\section{Reactive Centralization and Militarization of Policing}

Large scale protests against austerity measures and especially attempted storming of the Seimas on 16 January 2009 were totally unexpected occurrences and generated fear and apprehension of more unrest to come. By the evening of January $16^{\text {th }}$ and over that night, police officers had flooded into and cordoned off the area surrounding the Seimas in expectation of further assaults by hostile crowds. When these attacks did not materialized and prime minister Kubilius had regained his footing, the government hastily put in place a number of public order

measures to assure, as was stated by the General Commissar of the Police, that "January $16^{\text {th }}$ will never happen again" [52].

Among immediate measures undertaken by government was a request to the Seimas to fund the acquisition of mobile water cannon trucks, as well as placing new orders for tear-gas, rubber bullets, and other means of crowd control. Since the purchase and delivery of the water cannon vehicles would take time, the ministry of internal affairs was instructed to make inquiries about the possibility of borrowing similar equipment from Latvia or Poland. Simultaneously, the Seimas began debating changes in the police statute, to permit authorization of the use of water cannons. The police force itself also began discussing the use of dogs for crowd control purposes [53]. The Seimas also approved a new law authorizing the police in emergency situations to request help from, as well as participate in, operations in other EU and Schengen Area countries [54]. 
In September 2009 a two day-long training course was organized for officers from virtually all precincts of the country. It was led by top police commanders and the minister of internal affairs and included practical training in maneuvers designed to implement strategies and tactics of riot suppression. The training exercise was a part of broader changes introduced in the deployment of the national police force. More specifically, these changes entailed military- style coordination and integration with police officers deployed in squads under a centralized command and control structure.

Thus, in preparation for another rally organized by labor unions in October 2009, the police established barricades with entry posts to check the rucksacks and hold-all bags of participants. Mounted police and special riot units were present, dressed in military fatigues with flack-jackets, and with accompanying police dogs; extensive visible surveillance and videorecording of 371 participants of the rally was conducted who mainly comprised kindergarten staff, school teachers, and doctors. To the watching public and to the demonstration participants, it appeared that the oppressive police presence was an attempt at intimidation, there being almost as many police personnel present as protesters [55].

Similar intensive surveillance scenarios marked other demonstrations, by even quite small groups of protestors. In Kaunas a protest organized by the right-wing Lithuanian Freedom League on 23 January 2009 saw 300 police officers guarding about 400 protesters [56]; on February $4^{\text {th }}$, a rally organized by the leftist Socialist People's Front in front of the Seimas saw about 500 police officers in bullet-proof apparel and with (anti-barricade) battering rams, guarding about 200 protesters [57]. At times, these scenes bore an eerie resemblance to Soviet era policing tactics when intimidation by overwhelming force and extensive surveillance was used against small groups of protesting dissidents. By the early 2011, the police had created a 
special fenced in area near Seimas with manned security check points and command and control headquarters from which the police and the interior ministry leadership were able to watch live video feeds from multiple surveillance cameras ,mounted around the Seimas buildings.

The increasing use of military tactics and strategy was supported by significant organizational changes within the Lithuanian police force. In 2007 the Seimas adopted measures to reduce the number of local police headquarters from 54 by folding them into 10 regional divisions [58]. The 2009 unrest speeded up the centralization of the police force as locally accountable and more community-oriented municipal police units came under direct control and supervision of the national police headquarters. This allowed for the re-distribution and redirection of limited and shrinking police resources towards the strategic management of potential social unrest in the capital, Vilnius, and, to some degree, in other large cities. As resources from other regions were shifted towards the capital, policing in Vilnius was increasingly seen as being provided at the expense of public safety and security in other areas of the country [59].

These developments were indicative of an approach to policing in Lithuania, seen more in terms of war-fighting tactics, military based intelligence and equipment provision and training geared to achieve battlefield success. This predisposed officers deployed during protests to behave as surrogate soldiers, leading to needles roughness and violence against citizens. This had happened during the January $16^{\text {th }}$ unrest but was an already incipient tendency manifested in a number of prior incidents which attracted widespread public comment and unease (e.g., during Chinese president's visit to Lithuania in 2002 when a peaceful pro-Tibet demonstration was forcibly broken up and some of the demonstrators were 'manhandled' by the police; and in 2006 when 'People for Ethical Treatment of Animals' [PETA] members were arrested while demonstrating). January $16^{\text {th }}$ was part of an emergent patterned response behavior. 
The militarization and centralization of the police force since January 2009 has further reduced the capacity of officers to accommodate their actions in a situationally sensitive manner and to act with discretion when dealing with protesting citizens. Participants in protests were now to be routinely confronted by centrally coordinated detachments of police dressed in military style fatigues, masksand helmets, and armed with batons, battering rams, tear gas and rubber bullets. This represents a very worrisome shift towards policing by threat of violence rather than policing by consent. While a repressive policing posture tends to be more effective in the short run in controlling crowd situations, in the long run, it erodes human and civil rights and contributes to further spread of violence in society[60].

More specifically, reliance on military style methods threatens to further delegitimize the police and reduce cooperation with the general public. Consider unusually high levels of violence in police officers' relationships with citizens. In 2001 a survey of police officers in Vilnius, 45 per cent of participants reported being subjected to violence in police stations within twelve month period; a further 40 per cent indicated kicking or hitting someone. Levels of violence in police stations in Lithuania were twice the recorded rate of violence in police stations in Russia (although Russian police used lethal forced much more often)[61, p. 79]. In the press, police officers typically expressed growing fears of an 'increasingly aggressive public' as citizens lashed out at officers, at least in part because they perceived police actions to be either illegitimate, or disproportionate, or both [62]. Violent responses from citizens tend to further strengthen authoritarian tendencies in a negative feedback as officers in turn increase reliance on militarized tactics in confronting a seemingly aggressive public.

However, in addition to the worrisome drift towards militarization of the police force, there is an even more concerning tendency which is undermining the democratic right of dissent. 
This lies in the unyieldingly hostile state bureaucracy that confronts those citizens seeking to secure permission to voice their collective dissent within the public arena with an array of legalistic and administrative barriers in order to criminalize and restrict such protests.

\section{Criminalizing, restricting and litigating public protests}

Since introduction of austerity measures, and especially following 16 January 2009 events, authorities across the country and particularly in Vilnius attempted to increasingly curtail, restrict, and criminalize public protests. Reasons given for denying permits for holding protests tended to be twofold: the high likelihood that protests might threaten public safety and security, and the supposed presence of messages on internet instigating protesters to turn to violence [63]. Failure to obtain a permit and the holding of an unauthorized public event was punishable by a fine from 500 to 2,000 Lithuanian Litas (approximately $\$ 200$ to $\$ 800$ ) or administrative arrest for up to 30 days [64].

However, such decisions by local authorities denying permits for public protests were seen as impinging upon rights of assembly and free expression guaranteed by country's constitution, leading to litigation. Indeed, most such restrictions were over-ruled by courts as unconstitutional. Nevertheless, this did not discourage the authorities especially in the Vilnius municipality where most of the country's protests were held in routinely denying or placing various restrictions (such as on a maximum number of participants allowed) on petitions for permits. Therefore, in the capital of the country securing permits for rallies only after being sanctioned through the courts were now becoming a standardprocedure, not only for labor unions, but for other political or civic groups as well. 
For example, when the Vilnius municipality declined permit to Socialist People's Front (SPF), a relatively small leftist organization, to hold a rally in front of the Seimas on 16 January 2010 to commemorate the one year anniversary of the previous episode of unrest, the court reversed the refusal decision of the local authority. Facing hostile courts, the municipality changed its strategy in dealing with petitioners and chose to drag out and delay issuing decisions on petitions so that little time would be left for applicants to appeal rejections, far less for the courts to review ensuing complaints. Thus, on January $15^{\text {th }}$ the SPF finally was issued with court permission to hold its rally the following day. However, this gave insufficient time to prepare for the event thus blunting the effectiveness of the protest [65].

Similar developments occurred a year later. On 22 December 2010 the main confederation of labor unions, the Lithuanian Confederation of Labor Unions (LPSK) filed the required papers to the municipality requesting permission to hold a rally in front of Seimas. Labor unions claimed that they are organizing the event to protest a new round of austerity measures and budgetary cuts that Seimas had just voted upon., Vilnius municipality disagreed and argued that the rally was being held to commemorate 'the second anniversary' of the January $16^{\text {th }}$ riots. It offered the unions the option of re-locating the rally either to the suburbs, or to the city park which at that time of the year was covered in up to a meter thick layer of snow. The union leadership felt that such suggested alternative locations constituted a thinly veiled mockery and refused to reconsider their request for rally at a central location in front of the Seimas. The labor unions duly contested the municipality decision in court and won. On January $14^{\text {th }}$ the court ordered municipality to issue a permit to the labor unions to organize the rally. However, it took three further days, until January $17^{\text {th }}$, for municipality to issue a permit for a rally which was in fact to have been held a day earlier. 
When confronted by journalists as to why it took so long to comply with the court ruling, the mayor's office produced a complicated log of faxes and telephone calls, summoning the argument (in self-justifying bureaucratic-speak) that the court order was issued afterthe time of the day (4pm) when municipality offices were still open and able to process public business [66].

This scenario was repeated in February 2011, but with a new and more absurd twist. In the early December 2010 the trade union confederation applied for, but was denied a permit to hold a rally on 16 January 2011. The rally was to demand an increase in the minimum wage, a reversal of cuts in pensions, the introduction of progressive taxation, and subsidies for the poor to cover increased heating and water expenses. Instead a permit was granted for a rally to be held on February $19^{\text {th }}$ in front of Seimas, but with a stipulated maximum of 2,249 individuals. The municipality claimed that this was the number of participants that the square could safely accommodate.

Meanwhile the unions had recruited close to 1,500 of their members throughout the country to attend the rally and had made arrangements for their transportation and stay in Vilnius. However, three days before the rally a prominent national poet had died. A special government commission announced a national day of mourning and the state funeral for the poet to be held on February $19^{\text {th }}$, the day of labor union rally. In order to accommodate the funeral, the unions announced a change in time of their own proposed event. However, on February $17^{\text {th }}$, just two days before, Vilnius municipality unilaterally rescinded the labor unions' permit for the rally. Humiliating pleas by union leaders to the city hall functionaries that such large scale events with more than a thousand participants, were costly for unions to organize and required time to prepare (i.e., buses were already hired, speakers lined up, voice amplification equipment rented, stage pre-fabricated, demonstration paraphernalia prepared, etc.) were of no avail [67]. 
Nor was this the first time that the local authorities tried to set limits on the number of protesters in a seemingly arbitrary manner. Just a year before Vilnius municipality issued a permit for a protest rally in front of Seimas to a coalition of groups calling for 'For high quality and affordable higher education in Lithuania.' However the municipality limited the event to 300 participants only [68]. For civic and political groups organizing public protests, such an imposition of limits on numbers of participants increasingly appeared to be yet one more way in which authorities progressively sought to restrict rights of assembly guaranteed by the constitution. The leading national daily newspaper was provoked to comment that if the trend towards imposing new restrictions on public protests were to continue, then "soon we will need to acquire [individual] tickets from the authorities in order to participate in rallies" [69].

That restrictive local authority decisions could be repeatedly overruled by courts and still continue in an almost routine way would seem to suggest the dominance by far of executive over judicial branches of the government. The weakness of the courts as expressed in their failure to set a firm precedent and codify relationships between the authorities and citizens, as well as the failure to impose penalties on errant authorities for repeatedly violating the same provisions of the law, represent the legacy of Soviet times, when sentences were often dictated to judges by phone calls from the Communist party or KGB. Mid-level local authority bureaucrats who make up so-called 'Municipal events (meetings) coordination commissions' and take decisions on permits also complain for their part about being subjected to continuous pressure or 'criticism' or to direct meddling by members of Seimas and national government [63]. Therefore it comes as no surprise that local officials by far preferred simply to deny permits since such decisions were much safer than the fallout from protest rallies that could potentially go 'astray.' 
Finally, the weakness of a democratic and civic culture in the country, especially the lack of a tradition and culture of civic protest, also contributed towards growing restrictions on public protests in Lithuania. As tensions and discontent in society increased, so too did the repressive tendencies of authorities, especially in regard to public protests. Consider the speaker of Seimas, in comparing the proposed labor union rally to protest austerity measures to the onslaught of Soviet troops on the Supreme Council of Lithuania during the last days of the Soviet Union [70]; or the characterization by prime minister of trade union demands as 'calls for disturbances' which he refused 'to dignify with a response' [71]. One Seimas member even went so far as to openly ponder that "we already had $<$ Seimas $>$ windows broken; if people do not understand that it is inappropriate, then <protest rallies> should be banned" [63].

It is hard not to see close connections between a strengthening of a 'law and order' ethos of policing previously described, and a growing authoritarianism of public authorities tending to feed off and reinforce each other. As have been previously pointed out [33] such prohibitions and the numerous administrative obstructions, amounting in some cases to a virtual bureaucratic sabotage of public protest actions, tend to be experienced by citizens as typical expressions of the overbearing and arrogant attitude of the authorities towards powerless citizens. Furthermore, there is widespread frustration with the state officials for their lack of empathy, perceived acting in bad faith, their inability to address practical problems, and their neglect of citizens' needs. This is expressed in a superior and condescending attitude best summed up as: it is not they, the bureaucrats that are the servants of the public, but rather the reverse. This was of course, one of the underlying grievances that contributed to 16 January 2009 riots in the first place.

Like the militarized police force, the bureaucratically inured administrative apparatus has adopted a posture of hostility to the expression of dissent by ordinary citizens. In this respect, 
two key pillars of post-soviet democratic transformation, the executive and the police have been revealed as only at best conditionally attached to the democratic project and both as profoundly uneasy with any new challenges to the status quo. The consequences in terms of the build-up of unresolved tensions in society have had both deleterious and unexpected outcomes as the austerity crisis has deepened. Most unexpected of all, was the development of a new assertive collectivist consciousness among rank and file police officers as they too became victims of the austerity program imposed by government and in turn, sought to express their own dissent through public protest.

\section{Discontent within the police force}

One of the great ironies of the events of January $16^{\text {th }}, 2009$ was that those police officers guarding the Seimas shared many of the views of the demonstrators pelting the windows of the parliament with eggs and stones. Although first demonstrations by offduty police officers protesting austerity measures were held in front of Seimas as early as March of 2009, discontent had been simmering in the rank-and-file police force for a number of years [72], [73]. It was no accident that the police force was one of the few areas of the labor force that was highly unionized, and it was also not coincidental that the chairperson of the largest trade union confederation (LPSK) was himself a former serving police officer. Discontent was further fuelled by significant wage cuts resulting from the new program of austerity measures adopted by Seimas and the government. According to the government's budgetary office, in 2009 assignations to police were to decrease by $7.8 \%$ to 777.6 million Litas ( $\$ 309.71$ million); this included a $3.2 \%$ cut in the budget allocation for wages. However, what government statistics failed to state was that a significant part of rank-and-file police officers' wages included 
payments for overtime. As austerity measures had significantly reduced budgetary allocations for overtime, real wages for rank-and-file officers had declined by almost one fifth [74].

In response to growing discontent among its members, the National Association of Officers' Trade Unions (NAOTU) announced that it was preparing for 'massive and long term' protest actions to start in the late spring of 2009, initiating the so-called 'Barefoot officer -unsafe society' campaign. Its goal was to protest against police officers' increasingly impoverished conditions and present these as constituting a direct threat to public safety and the security of the citizenry. The execution of the barefoot campaign centered on an effective publicity-generating element of street theatre. At a designated time, when picketing government offices, officers dressed in uniform took off their shoes and socks for five minutes in a symbolic demonstration of the impact that austerity measures had had on police force.

It is important to note that the fallout of barefoot protests also included a considerable increase in conflicts and tensions between the labor union and the top echelons of the force. In part, this was a reaction of commanding officers to what they perceived to be outright ridiculing by subordinates and their discomfiture at being forced to explain and defend their position in public. At the same time, the police leadership was also increasingly subjected to strong Seimas and government pressure to reign in internal dissent, as well as to assure police loyalty and effective subordination. Thus the minister of internal affairs and his staff went on a public offensive accusing the labor unions of blackmailing the government, of denigrating the uniform and the symbols of law enforcement, and of attempting to manipulate and scare the public [75].

Tensions between commanding and rank-and-file officers increased even further when by the mid-April 2009 the government, facing larger shortfalls of revenue than previously anticipated, began to revise the national budget and proposed an additional 55 million Litas (\$2.2 
million) reduction in the police budget. This included such measures as extended mandatory furloughs for officers and a reduction in staffing as well as in the number of patrol cars. The police trade union (NAOTU) was infuriated and declared that by proposing new cuts the government was seeking to humiliate and destroy the police force; that dialog with the government was impossible and that the labor unions would immediately launch a second round of 'barefoot' campaigning.

Facing what increasingly looked like a revolt within the police force, the prime minister personally intervened to diffuse the situation. A special commission was created to review the situation and within two weeks agreement was reached between the prime minister and NAOTU on revising the police budget and transferring additional 9 million Litas (\$3.6 million) to compensate for cuts in police wages with promises for still more additional funding. In return, the labor union agreed to call off its barefoot demonstrations scheduled for the end of April [76].

By the summer of 2009 tensions between commanding and rank-and-file officers began to resurface again as attempts to find additional funding, predictably, fizzled out. Evidence of the growing suspicion between leadership and rank-and-file seemed to be confirmed when officers active in the labor union in the precinct of Kaunas found themselves being clandestinely bugged by listening devices. In addition activists complained of being subjected to what they called 'harassment' by the ministry of internal affairs and under increasing pressure to quit the force. Up until the developments in Kaunas, NAOTU had tried to limit its agenda and campaigns mostly to economic issues. The 'bugging scandal' radicalized and politicized the labor union: it launched a public campaign to force resignation of the interior minister [77].

As economic crisis continued to worsen throughout late 2009, prospects for fending off further cuts in police financing in the forthcoming budget for the 2010 financial year were 
diminishing: by August 2009 the government proposed cuts which were to amount to a $21.3 \%$ reduction in the police budget. The police department ??? immediately issued statement alleging that such draconian cuts would result in lay-offs of about 900 police personnel (6\% to $7 \%$ of the total force), and therefore represented a direct threat to public safety and security of the country [78].

Negotiations between the commissar general of the police and NAOTU on how to structure the forthcoming cuts proved to be very tense. Thus, NAOTU chairman Bakas voiced his concerns about growing danger of insubordination within the force stating that "if someone, say a new and yet unknown populist leader of the nation were to decide to organize a new January $16^{\text {th }}$, I am very doubtful that one would able to find within the deeply discontented and demoralized police force the necessary officers who would be willing to protect the Seimas" [79].

Later in an extensive interview with the conservative daily newspaper 'Respublika,' Bakas reiterated his view that deepening austerity measures could significantly increase risks of "social explosions $<\ldots>$ and the possibility of a new wave of riots in the country. $<\ldots>$ If politicians were to remain blind to the risks associated with cutting wages of police officers, then next year could potentially start with a wave of riots that police officers themselves could join out of despair. It is because of budgetary cuts that potentially could leave close to 900 officers unemployed, while the rest had their wages cut to up to quarter" [80].

It is difficult to estimate the credibility of Bakas' claims in regard to possibility of insubordination among rank-and-file police officers because (with an exception of the January $16^{\text {th }}, 2009$ episode), the Lithuanian police have not thus far faced the task of upholding public order against large masses provoked and mobilized by unpopular decisions of the authorities. At 
the same time, it did seem that police labor union leadership was using such controversial statements, in part, to put pressure on senior police officers while in negotiation over their own demands.

Nevertheless, the determination by the government to ram through austerity measures even at the potential cost of widespread disaffection among the police force was, to say the least, a high risk strategy. There is a historical precedent for such insubordination within the force during perestroika era when Lithuanian police officers en masse refused to enforce Moscow's directives. We also have some anecdotal evidence of police officers contemplating fraternization with protesters during the January $16^{\text {th }} 2009$ events. In one episode, correspondents of a major daily newspaper describe such an exchange between a policeman and a group of women who came to the rally (this is before the riot began). A policeman was telling to protesting women "Please understand that such is our job. I am in agreement with all what you are protesting against. I myself would gladly take my uniform off to join you, but I can't” [81]. Among other previous cases of police insubordination in the wider East European region there was a national road blockade by the taxi drivers which paralyzed Hungary in October 1990furing which the police did not enforce the law on assembly and instead fraternized with the drivers [82]. Threats of insubordination illustrate that police unions potentially have significant leverage vis-à-vis democratic governments because they could leave the state paralyzed when confronted with populations mobilized by high levels of discontent and grievance.

\section{Implications for policing: democracy and dissent in post-communist society}

In the crucible of economic crisis, the connective social compact between citizen and state had been profoundly damaged. Indeed the state itself was now revealed not just as 
bureaucratically unresponsive and even hostile towards the rights of ordinary citizens seeking to give voice to legitimate protest demands, but as a visible apparatus of repression in which an increasingly militarized policing of public protest had become the front line of a new authoritarianism. This 'loss of faith' was acutely summed up by none other than prime minister Kubilius himself: 'In the spiritual sense, we have a lot of people disappointed with their authorities and the state, citizens who believe in nothing, and we must breathe self-confidence and trust in a common Lithuanian future into these citizens' [83]. Since the beginning of the 2008 crisis, labor union activism and especially its visibility in Lithuania had increased significantly. Ironically, from being reviled as passive instruments of the former regime, the trade unions now became more trusted civil society organizations achieving a new level of popular legitimacy. For the first time in close to two decades since independence, labor unions began to be included in public opinion surveys designed to measure public trust in number of institutions. Surveys conducted by polling firm 'Baltijos Tyrimai' had shown that in 2008, 38\% of respondents trusted labor unions, while 36\% did not; in 2009 these numbers were correspondingly $42 \%$ and $36 \%$ and in $2010-37 \%$ and $40 \%$ [84],[85]. The decline in trust to 2009 levels in the latest year reflects perhaps the visible failure of the broader trade union movement to halt the onslaught of successive waves of austerity measures. These most recent data in turn can be qualified by the high profile struggle that police labor union waged in defending the economic wellbeing and rights of its members.

The resolution of the crisis by government based on a strategy of 'internal devaluation' has resulted in a concerted attack on popular living standards, further undermining of any pretence of social justice in society. In such a fraught environment the maintenance of social order would appear to rest not so much upon popular 'acquiescence', as a reflex response by the 
state towards greater authoritarianism in suppressing dissent. It would appear that when necessary, the authoritarian reflex of post-communism does not reside simply in the realm of the aggressive promotion of free-market ideology and hyper-individualism ('disciplinary’ neoliberalism) [86]but on the exercise of the ultimate power of the state and its monopoly of the instruments offorce.

In the context of contemporary Baltic Lithuania, the term 'Belarussification' draws attention to the drift towards an authoritarian response set in dealing with expressions of dissent that bears uncomfortable similarities to the prevailing regime response of its geographic near neighbor. It would seem that in Lithuania repressive policing strategies exactly conform to the objective needs of the broad conjuncture of a global and of a post-communist crisis of social order. Regular policing personnel who are themselves victims of austerity cuts may not be wholly reliable and that reinforces the increasing recourse to paramilitary units and tactics in the face of renewed unrest. Paradoxically, even as the 'post-communist' state instinctively reproduces authoritarian and militarized responses, the primary arm of its public order enforcement strategy is internally riven by the very tensions which appear to be conflicting the wider society.

\section{Notes}

1. Of course, this could also happen in cases when violent criminal groups become powerful enough to challenge and even displace state authorities, as is currently the case in Mexico where armed narco groups are waging war against federal army and police for control of regions bordering the US[87]. However, even at their peak of power (in the early 1990s) organized 
criminal groups in the Baltics had never had a power that even remotely compares to the current situation in Mexico.

\section{REFERENCES}

1. International Labor Organization, T. (2011). World of Work Report 2011. Geneva: International Institute for Labour Studies.

2. Apps, P. (2010). Analysis: Europe faces rising austerity protests in 2011. Reuters, December 15. http://www.reuters.com/article/2010/12/15/us-europe-protestsidUSTRE6BE3FK20101215, accessed 21 April 2011.

3. Lannin, P. (2009). Riots expose roots of anger on EU's edges. Reuters, January 19. http://uk.reuters.com/article/2009/01/19/uk-financial-europe-unrestidUKTRE50I0A020090119, accessed 21 April 2011.

4. Druker, J. (2009). Rioting Eastern Europe. ISN ETH Zurich, January 23. http://www.isn.ethz.ch/isn/Current-Affairs/Security-WatchArchive/Detail/?lng=en\&id=95684, accessed 21 April 2011.

5. Barry, E. (2009). Baltic riots spread to Lithuania in the face of deteriorating economic conditions. The New York Times, January 17. http://www.nytimes.com/2009/01/17/world/europe/17lithuania.html, accessed 21 April 2011.

6. Barry, E. (2009). Latvia is shaken by riots over its weak economy The New York Times, January 14. http://www.nytimes.com/2009/01/15/world/europe/15latvia.html, accessed 21 April 2011.

7. Duxbury, C. (2010). Irish should look to Baltics, not Iceland. Wall Street Journal, December 10. http://blogs.wsj.com/source/2010/12/10/ireland-should-take-heart-from-the-balticsand-not-envy-the-icelanders/, accessed 21 April 2011.

8. Looby, J. (2011). A Latvian solution to an Irish problem? Business and Finance, February. http://www.businessandfinance.ie/bf/2011/1/marketseconomicsjan2011/alatviansolutiont oanirishprobl, accessed 21 April 2011.

9. Samuelson, R. (2011). What we can learn from Latvia's economic recovery. Washington Post, July 17. http://www.washingtonpost.com/opinions/what-we-can-learn-from-latviasrecovery/2011/07/17/gIQAelvcKI_story.html, accessed 21 April 2011.

10. Aslund, A., \& Dombrovskis, V. (2011). How Latvia Came Through the Financial Crisis. Washington, DC: Peter G. Peterson Institute for International Economics

11. Forbes, S. (2010). Europe's unsung heroes. Forbes Magazine June 8. http://www.forbes.com/global/2010/0607/opinions-steve-forbes-lithuania-recession-factcomment.html, accessed 21 April 2011.

12. Economist, T. (2009). No panic, just gloom. May 14. http://www.economist.com/world/europe/displayStory.cfm?story_id=13650051, accessed 21 April 2011.

13. Hudson, M., \& Sommers, J. (2010). Latvia provides no magic solution for indebted economies. Guardian, December 20. 
http://www.guardian.co.uk/commentisfree/2010/dec/20/latvia-debt-economy-europeausterity, accessed 21 April 2011.

14. Hudson, M., \& Sommers, J. (2011). The myth of the Baltic Tigers and the death of "social Europe". Conterpunch, January 18. http://www.counterpunch.org/hudson01182011.html, accessed 21 April 2011.

15. Sommers, J., \& Hudson, M. (2011). Latvia and the disciples of 'internal devaluation'. The Guardian, September 16. accessed 21 April 2011.

16. Sommers, J. (2010). Latvia's "Mandate" for Neoliberal Austerity Counterpunch edited by Alexander Cockburn and Jeffrey St.Clair, October 6. accessed 21 April 2011.

17. Bodnar, A. (2009). Shaping the freedom of assembly: Counter-productive effects of the Polish road towards illiberal democracy. In A. Sajo (Ed.), Free to Protest: Constituent Power and Street Demonstration (pp. 165-187). Ultrecht, the Netherlands: Eleven International Publishing.

18. Sajo, A. (Ed.). (2002). Out of and into Authoritarian Law. The Hague: Kluwer Law International.

19. Los, M. (2002). Post-communist fear of crime and the commercialization of security. Theoretical Criminology, 6(2), 165-188.

20. Los, M., \& Zybertowicz, A. (2000). Privatizing the Police-State: The Case of Poland. New York: St. Martin's Press.

21. Juska, A. (2009). Privatization of state security and policing in Lithuania. Policing and Society, 19(3), 226-246.

22. Ceccato, V., \& Lukyte, N. (2011). Safety and sustainability in a city in transition: The case of Vilnius, Lithuania. Cities, 28(1), 83-94.

23. Szikinger, I. (1998). Tendencies of militarization in Central and Eastern European policing. In M. Pagon (Ed.), Policing in Central and Eastern Europe: Organizational, Managerial, and Human Resource Aspects (pp. 29-38). Ljubljana: College of Police and Security Studies.

24. King, M., Koci, A., \& Bukauskas, A. (2007). Policing social transition: Public order policing change in Lithuania. Policing, 1(4), 428-437.

25. Sajo, A. (Ed.). (2009). Free to Protest: Constituent Power and Street Demonstration. Ultrecht, the Netherlands: Eleven International Publishing.

26. Szabo, M. (1996). Repertoires of contention in post-communist protest cultures: An East Central European comparative survey. Social Research, 63(4), 1155-1182.

27. Szabo, M. (2009). Demonstration Democracy in Hungary: Policing protest - from the catacomb of unoffical activities to rioting. In A. Sajo (Ed.), Free to Protest: Constituent Power and Street Demonstration (pp. 221-242). Ultrecht, the Netherlands: Eleven International Publishing.

28. Szabo, M. (1997). From a "Police State to a Demonstration Democracy." Policing Mass Demonstrations in Hungary Budapest: Institute for Political Science of Hungarian Academy of Sciences.

29. Misztal, B., \& Jenkins, J. C. (1995). Starting from scratch is not always the same: The politics of protest and the postcommunist transitions in Poland and Hungary. In J. C. Jenkins, \& B. Klandermans (Eds.), The Politics of Social Protest: Comparative Perspectives on States and Social Movements (pp. 159-166). Minneapolis: University of Minnesota Press. 
30. Paulauskas, D. (2011). Protestas ar gedulas? Delfi.lt, January 19. http://www.delfi.lt/news/ringas/lit/dpaulauskas-protestas-ar-gedulas.d?id=41004741, accessed 21 April 2011.

31. Vasiliauskiate, N. (2011). Apie viesas erdves, Sajudi ir Nauja Kaire. Delfi.lt, January 31. http://www.delfi.lt/news/ringas/lit/nvasiliauskaite-apie-viesas-erdves-sajudi-ir-naujakaire.d?id=41475635, accessed 21 April 2011.

32. Diamond, L. J. (2008). The Spirit of Democracy: The Struggle to Build Free Societies Throughout the World (1st ed.). New York: Times Books/Henry Holt and Company.

33. Woolfson, C., \& Juska, A. (2011). Economic crisis and social unrest in Lithuania: Prospects for postcommunist trade union renewal. Debatte: Journal of Contemporary Central and Eastern Europe.

34. Misiunas, R., \& Taagepera, R. (1993). The Baltic States, Years of Dependence, 1940-1990 (2d ed.). Berkeley: University of California Press.

35. Gutauskas, A., Juska, A., Johnstone, P., \& Pozzuto, R. (2004). Changing typology of organized crime in post-socialist Lithuania (the late 1980s - early 2000s). Global Crime, $6(2), 195-215$.

36. Guidelines of the Lithuanian Police Reform (1997). Government of the Republic of Lithuania. Resolution No. 1336. Vilnius.

37. Sakocius, A. (2007). Police and Internal Security System Reform in Lithuania (1990-2007). Vilnius: Ministry of the Interior of Lithuania.

38. Koci, A. (1998). Reform of the police in Hungary and Lithuania: Empirical findings on the policing of public order. Innovation, 11(3), 307-314.

39. Juska, A. (2007). Discourses on rurality in post-socialist news media: The case of Lithuania's leading daily 'Lietuvos Rytas'. Journal of Rural Studies, 23(2), 238-253.

40. Gadeikis, L. (2001). Subsistence farming - no way to new economy. Lithuanian Business Review, April. accessed 21 April 2011.

41. Laurenas, V. (2004). Politine krize Lietuvoje 2003-2004 metais. Politologija, 35(3), 1-34.

42. Juska, A., \& Johnstone, P. (2004). The symbiosis of politics and crime in Lithuania. Journal of Baltic Studies, XXXV(4), 346-359.

43. ELTA. (2011). Protesto kulturos nebuvimas uzkerta kelia tikrosios demokratijos link. ATN.LT, February 10. http://politika.atn.lt/straipsnis/73487/protesto-kulturos-nebuvimasuzkerta-kelia-tikrosios-demokratijos-link, accessed 21 April 2011.

44. Aidukaite, J. (2009). Transformation of welfare systems in the Baltic states: Estonia, Latvia and Lithunia. In A. Cerami, \& P. Vanhuysse (Eds.), Post-Communist Welfare Pathways: Theorizing Social Policy Transformations in CEE (pp. 96-112). Basingstoke, UK: Palgrave Macmillan.

45. Bohle, D., \& Greskovits, B. (2007). Neoliberalism, embedded neoliberalism and neocorporatism: Towards transnational capitalism in Central-Eastern Europe. West European Politics, 30(3), 443-466.

46. World Bank (2005). Doing Business in 2006: Eastern European and Baltic Nations Encourage Businesses with Aggressive Regulatory Reforms. Press Release, 12 September. Washington, DC: World Bank.

47. Eurostat (2009). Newsrelease, euroindicators, 121/2009, 24 August. Brussels: The Statistical Office of The European Union.

48. Eurostat (2010). First estimates for the fourth quarter of 2009, euroindicators 34/2010 - 4 March. Brussels: The Statistical Office of The European Union. 
49. Economist, T. (2009). Ex-communist economies. The whiff of contagion. February 26. http://www.economist.com/world/europe/displaystory.cfm?story id=13184594, accessed 21 April 2011.

50. Skvernelis, S., \& Lancinskas, K. (2009). Protesto akcijoje dalyvavo maksimalios pareigunu pajegos. Balsas.lt, January 16. http://www.balsas.lt/naujiena/233286/protesto-akcijojedalyvavo-maksimalios-pareigunu-pajegos, accessed 21 April 2011.

51. Jackevicius, M., Saukiene, I., Utyra, E., Digryte, E., \& Lukaityte, E. (2009). Riausese prie Seimo 151 chuliganas sulaikytas, 34 mitingo dalyviai suzeisti. Delfi.lt, January 16. http://www.delfi.lt/news/daily/lithuania/article.php?id=20111082, accessed 21 April 2011.

52. Telycenas, V. (2009). V.Telycenas: sausio 16-osios ivykiai nepasikartos. 15min.lt, December 7. http://m.15min.lt/id/aktualu/lietuva/vtelycenas-sausio-16-osios-ivykiai-nepasikartos56-74676, accessed 21 April 2011.

53. Povilaitis, N. (2009). Riauses Vilniuje malsines generolas S.Madalovas sako, kad kitakart bus panaudoti ir tarnybiniai sunys. Lietuvos Rytas, January 27. http://www.lrytas.lt/12329790191231617380-riau\%C5\%A1es-vilniuje-mal\%C5\%A1in\%C4\%99s-generolass-madalovas-sako-kad-kit\%C4\%85kart-bus-panaudoti-ir-tarnybiniai-\%C5\%A1unys-4video.htm, accessed 21 April 2011.

54. BNS. (2009). Lietuvos policija galès kviestis pagalbą iš ES ir Šengeno šalių. Alfa.lt, October 22.

http://www.alfa.lt/straipsnis/10295920/?Lietuvos.policija.gales.kviestis.pagalba.is.ES.ir.S engeno.saliu=2009-10-22_13-04., accessed 21 April 2011.

55. Vysniauskiene, B. (2009). Kiekvienam piketuotojui - po ginkluota policininka. Lietuvos Rytas, October 22. accessed 21 April 2011.

56. Karaliunas, A. (2009). Trims protestuotojams teko vienas tvarkos saugotojas. Lietuvos Rytas, January 23. accessed 21 April 2011.

57. Traceviciute, R. (2009). "Fronto" svogunai atsirugs biudzetui. Lietuvos Zinios, February 4. accessed 21 April 2011.

58. Laucius, V. (2010). V.Telyčėnas: sausio 16-oji tikrai nepasikartos. Delfi.lt, January 11. http://www.delfi.lt/news/daily/lithuania/vtelycenas-sausio-16-oji-tikrainepasikartos.d?id=27673685, accessed 21 April 2011.

59. BNS. (2009). Policija skundziasi, kad del mitingu nukencia saugumas kitose vietose. Lietuvos Rytas, December 14. http://www.lrytas.lt/-12608023341259788697-policijaskund\%C5\%BEiasi-kad-d\%C4\%971-miting\%C5\%B3-nuken\%C4\%8Dia-saugumaskitose-vietose.htm?id=12942077151294038970\&view=6, accessed 21 April 2011.

60. Weber, D. C. (2009). Militarization of law enforcement. DarkGovernment, September 30. http://www.darkgovernment.com/news/militarization-of-lawenforcement/\#ixzz1E4Rke0a5, accessed 21 April 2011.

61. Uildriks, N., \& Reenen, v. P. (2003). Policing Post-Communist Societies. Police-Public Violence, Democratic Policing and Human rights. Antwerp, Oxford and New York: Intersentia and Open Society Institute.

62. Vysniauskiene, B. (2009). Policija bijo agresyvejancios visuomenes. Lietuvos Zinios, November 2. http://www.vtv.It/naujienos/lietuvoje/policija-bijo-agresyvejanciosvisuomenes-15.html, accessed 21 April 2011.

63. Kranauskas, L. (2011). Mitingu menuo (ne)patekejo Atgimimas, February 18. http://www.atgimimas.lt/Diskusija/Mitingu-menuo-ne-patekejo, accessed 21 April 2011. 
64. LR ATKP 188-7. (1994). Lietuvos Respublikos administraciniu teises pazeidimu kodeksas 188-7 straipsnis. Lietuvos Respublikos Seimas., http://www.infolex.lt/ta/103787:str188-7, accessed 21 April 2011.

65. Gabrilaviciute, L. (2010). Prie Seimo gincijosi mitinguotojai ir policininkai. 15min.lt, January 15. http://www.15min.lt/naujiena/aktualu/lietuva/prie-seimo-gincijosimitinguotojai-ir-policininkai-56-79966, accessed 21 April 2011.

66. Samoskaite, E. (2011). Leidima mitinguoti sausio 16-aja isdave sausio 17 d. Delfi.lt, January 19. http://www.delfi.lt/news/daily/lithuania/leidima-mitinguoti-prie-seimo-sausio-16-ajaisdave-sausio-17-d.d?id=41018363, accessed 21 April 2011.

67. ELTA. (2011). Anuliavus leidima, profsajungos ruosiasi nesankcionuotam mitingui. Delfi.lt, February 17. http://www.delfi.lt/news/daily/lithuania/anuliavus-leidima-profsajungosruosiasi-nesankcionuotam-mitingui.d?id=42122195, accessed 21 April 2011.

68. Delfi. (2009). Dideliems mitingams Vilniuje - raudona sviesa. Delfi.lt, February 24. http://www.delfi.lt/news/daily/lithuania/dideliems-mitingams-vilniuje-raudonasviesa.d?id=20712233, accessed 21 April 2011.

69. Ignatavicius, T. (2011). I busimus mitingus - tik su bilietu? Lietuvos Rytas, February 9. http://www.Irytas.1t/-12972302331296824670-\%C4\%AF-b\%C5\%ABsimus-mitingus-tiksu-bilietu.htm, accessed 21 April 2011.

70. Saukiene, I. (2009). Kodel miniai skanduojant "Lietuva" duzo langai? Delfi.lt, January 19. http://www.delfi.lt/news/daily/lithuania/kodel-miniai-skanduojant-lietuva-duzo-seimolangai.d?id=20180411, accessed 21 April 2011.

71. Zelniene, L. (2011). A.Kubilius: mitingas - ne vieta deryboms. Diena.lt, February 7. http://www.diena.lt/naujienos/ekonomika/a-kubilius-mitingas-ne-vieta-deryboms$\underline{331078}$, accessed 21 April 2011.

72. Jancys, A. (2009). Angelu sargu gretos reteja. Lietuvos Rytas, March 21. http://www.policija.lt/index.php?id=5259, accessed 21 April 2011.

73. Bareisis, A. (2009). Pries algu mazinima protestavo ir kartoninis policininkas. Alfa.lt, March 27. http://www.alfa.lt/straipsnis/10265979, accessed 21 April 2011.

74. Bartasevicius, V. (2009). Mazes policijos algos - mazes ir saugumas. Lietuvos Rytas, March 30. http://www.lrytas.lt/-12383880461236776074-ma\%C5\%BE\%C4\%97s-policijosalgos-ma\%C5\%BE\%C4\%97s-ir-saugumas.htm, accessed 21 April 2011.

75. Kuznecovaite, A. (2004). Pakso salininkus valde jausmai. Lietuvos Zinios, April 07. accessed 21 April 2011.

76. ELTA. (2009). Pareigunai atideda protesto akcija. Vakaru Ekspresas, April 23. http://www.ve.lt/naujienos/lietuva/lietuvos-naujienos/pareigunai-atideda-protesto-akcija/, accessed 21 April 2011.

77. BNS. (2009). Pareigunu profesines sajungos: "R.Palaitis negali eiti vidaus reikalu ministro pareigu“. Lietuvos Rytas, July 16. http://www.Irytas.1t/-12477457251247367967pareig\%C5\%ABn\%C5\%B3-profesin\%C4\%97s-s\%C4\%85jungos-r-palaitis-negali-eitividaus-reikal\%C5\%B3-ministro-pareig\%C5\%B3.htm, accessed 21 April 2011.

78. Policijos Departamentas. (2009). PD: kitamet planuojama atleisti 900 policininku. Delfi.lt, August 17. http://www.delfi.lt/news/daily/lithuania/article.php?id=23605932, accessed 21 April 2011.

79. Paknys, A. (2009). Uzdarbis mazes ketvirtadaliu. Respublika, August 27. accessed 21 April 2011. 
80. Bakas, V. (2009). Lietuvos saugumui - bomba. Respublika, September 11. accessed 21 April 2011.

81. Mikalajunas, T., \& Vaitonis, S. (2009). Reporteriu zvilgsnis i Seima is riausininku minios pro asariniu duju dumus. Lietuvos Rytas, January 17. http://www.lrytas.lt/$12321236481231106814-1 r y t a s-1 t-r e p o r t e r i \% \mathrm{C} 5 \% \mathrm{~B} 3-\% \mathrm{C} 5 \% \mathrm{BEvilgsnis}-\% \mathrm{C} 4 \% \mathrm{AF}-$ seim\%C4\%85-i\%C5\%A1-riau\%C5\%A1inink\%C5\%B3-minios-proa\%C5\%A1arini\%C5\%B3-duj\%C5\%B3-d\%C5\%ABmus-video-nuotraukos.htm, accessed 21 April 2011.

82. Szabo, M. (1993). Social protest in post-communist democracy: The taxi drivers' demonstration in Hungary In J. Frentzel-Zagórska (Ed.), From a One-party State to Democracy: Transition in Eastern Europe (pp. 113-136). Amsterdam-Atlanta: Rodopi B.V.

83. Baltic Times. (2009). PM: public funds, business sector and social peace are priorities. April 15. http://www.baltictimes.com/news/articles/22716/, accessed 21 April 2011.

84. ELTA. (2010). Apklausa: pasitikejimo nusipelno ugniagesiai, Seimas - jo nevertas. Delfi.lt, November 15. http://www.delfi.lt/news/daily/lithuania/apklausa-pasitikejimo-nusipelnougniagesiai-seimas---jo-nevertas.d?id=38608773, accessed 21 April 2011.

85. Steponas, J. (2011). Pilieciai nusivilia profesinemis sajungomis? Profsajungu Naujienos, January 10. http://www.lprofsajungos.lt/?lang=lt\&mID=1\&id=3733, accessed 21 April 2011.

86. Gill, S. (2004). New constitutionalism, democratization and global political economy. In R. Wilkinson (Ed.), The Global Governance Reader (pp. 176-186). London: Routledge.

87. Grillo, I. (2011). El Narco Inside Mexico's Criminal Insurgency. New York: Bloomsbury Press. 